\title{
Interactions of an anionic antimicrobial peptide with Zinc(II): application to bacterial mimetic membranes
}

Bashiyar Almarwani, Nsoki Phambu, Yahia Z. Hamada, and Anderson Sunda-Meya

Number of pages: 1

Number of Figures: 1 


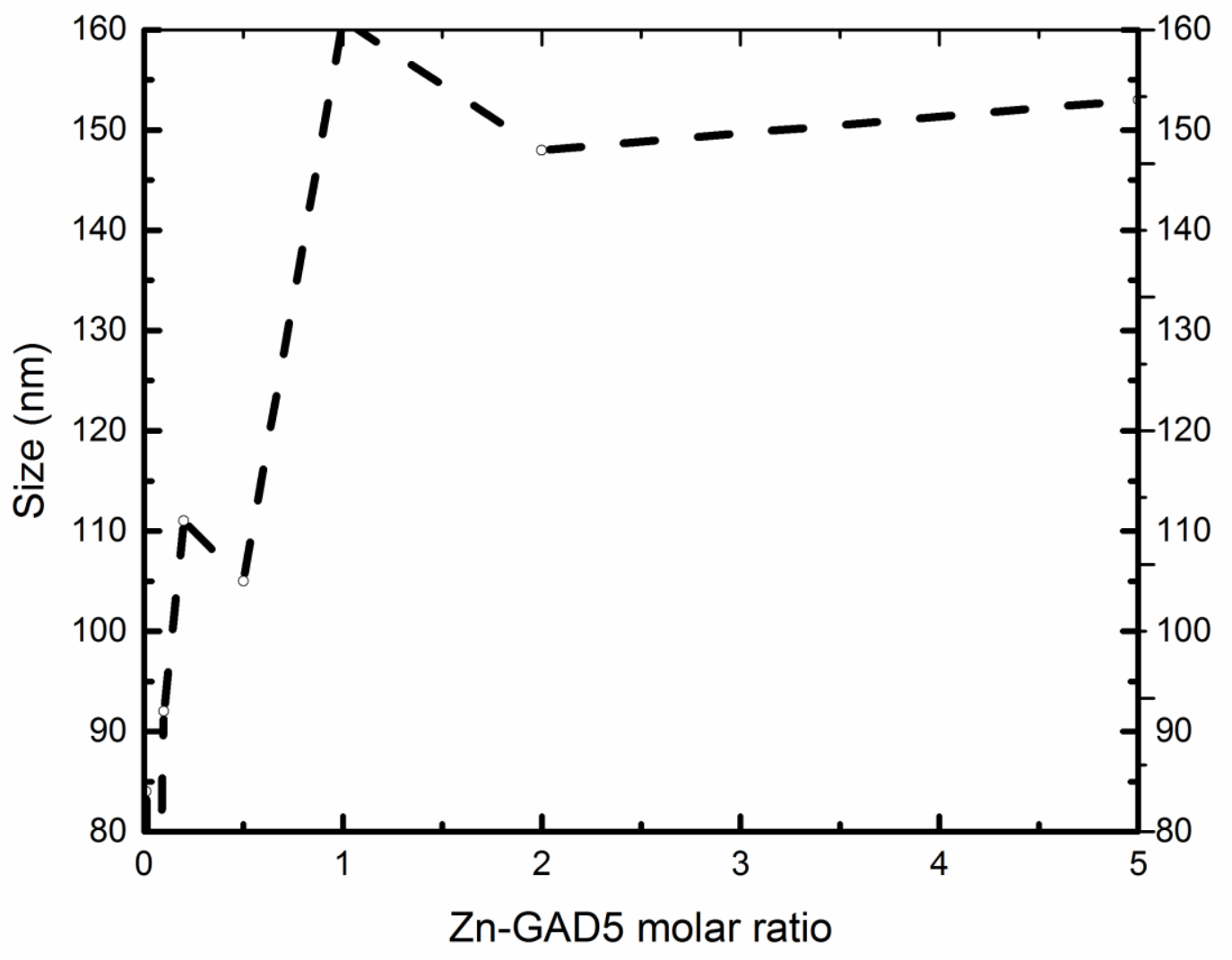

Figure 1S. Particle sizes of Zn-GAD5 at various molar ratios, measured by dynamic light scattering. 